\title{
Agricultural land use changes according LPIS in Brno Metropolitan Area
}

\author{
Jan Vachuda \\ Masaryk University, Czech Republic
}

Territorial changes of agriculture land use between 2008 and 2013 were studied in the Brno Metropolitan Area, consisting of the territory of 167 municipalities around the city of Brno, Czech Republic. The article describes the ways of thinking about land use changes and evaluates differences of land use changes between agriculture system LPIS and Cadastre. Analyses identify differences between databases and detected partial outdated data in Cadastre and therefore conclude, that the most common source is not in some cases precise to express the situation of decreases of agriculture land. The largest decreases were caused according to LPIS by a construction of solar power plants, sand quarries, and urbanization. The end of the article is focused on raising awareness about the possibilities of reducing the negative impact of changes in agricultural land, which emphasizes the education about land use changes irreversibility as the most important.

Key Words: agricultural land use, land use changes, change areas, LPIS, Brno Metropolitan Area, agriculture.

Article Info: Received: October 25, 2016; Revised: November 10, 2016; Accepted: November 19, 2016; Online: November 30, 2016.

\section{Introduction}

Land use changes in developed countries are mostly driven by changes in agriculture, forestry, and urbanization (Rounsevell et al., 2006). Long-term studies (on land use changes) in the Czech Republic (CR) describe that over the past 150 years the changes in agriculture land use are a reflection of the economic, social and political changes (Bičík, Jeleček, 2009).

Research on land use changes is very important, because monitoring is the

\footnotetext{
* Correspondence address

Address: Department of Geography, Faculty of Science, Masaryk University

Kotlářská 267/2, 61137 Brno, Czech Republic.

Email: pelco@mail.muni.cz
} 
cornerstone for further application. Analysis of landscape changes is equally important from the point of view of assessing natural and socio-economic process, its dynamic and causes, as well as possible trends of future development (Feranec et al., 2000).

In this case study, we use the national LPIS data of the CR for the years 2008-2013 to improve the understanding of changes of agricultural land near Brno city (Brno Metropolitan Area). The goal is to show the advantages and disadvantages of using spatial data of the Land parcel identification system (LPIS) rather than national cadastral statistics and make possible conclusions for implementing of strategies for protection of soil.

Three hypothesis say: (1) Agricultural land in Brno Metropolitan Area differs between data of LPIS and Czech cadastral office (Cadastre), (2) Use of the LPIS data for assessing land use changes will increase the accuracy of land use changes understanding in Brno Metropolitan Area (because LPIS is spatially more precise, cadastral statistic is used in all areas of the village) and (3) localization of highest decrease can be found near areas with high residential and industrial suburbanization.

\section{Literature review}

There are many ways of thinking about the research of land use changes (Hynek, Vávra, 2011, Holloway et al, 2003, Kuhn, 1962). The tab. 1 describes basic approaches, concepts, and theoretical framework of perception of the problem of land use changes. Prevailing approaches in the studies of land use can be interpreted as quantitative approaches particularly affected with the development of technologies (spatial science). The common method in the Czech environment consists of using statistical methods for the area of agricultural land in municipalities or cadastral units (Bičík et al., 2010), which is, in particular, the methodology close to the methodology in this article. Spatial analysis of the LPIS also carries out foreign authors (Zimmermann et al., 2016). Influential approaches of land use changes are particularly concerned to the physical surface (land cover). "Spatial science" is criticized in the partial shift of paradigm in Czech geography, but results are useful in small scale and they have often published: e.g. the method of change of land cover using remote sensing methods (Anděl, Balej, 2011, Feranec et al., 2000). In particular, quantitative methods also include changes found in the map (Lipský, 2000, Skokanová et al, 2012), which are produced thank the development of statistics and technologies for processing geospatial information.

An important part of scientific discourse consists of approaches used in regional development documents (strategies); technical approaches (land reforms), landscape planning (Sklenička, Pixová, 2004) and also partially the approaches addressed in rural sociology (Delín, Pospěch, 2016). The structural approach focused on the agricultural sector or rural transformation is seen as more influential (Věžník et al., 2013; Woods, 2005).

Land parcel identification system (LPIS) is the important source of data about soil sealing, and about changes in agricultural land use. LPIS is used for evaluation of changes in more studies (Zimermann et al., 2016; Levin, 2013). 
Table 1. Selection of approaches to conceptualization of land use changes

\begin{tabular}{|c|c|}
\hline $\begin{array}{l}\text { Name of approaches, } \\
\text { narratives }\end{array}$ & Ways of thinking, key concepts, interpretation, ideas \\
\hline Natural determinism & $\begin{array}{l}\text { Changes influenced by physical geographic phenomena (soil, } \\
\text { slope, climate, rainfall, stoniness, hydrology) }\end{array}$ \\
\hline Social determinism & $\begin{array}{l}\text { The influence of society, the events of history and technology } \\
\text { at the time (i.e. the concept of natural selection) }\end{array}$ \\
\hline Nomothetic & $\begin{array}{l}\text { Quantification of generalization, creation of categorization, } \\
\text { space }\end{array}$ \\
\hline Idiographic & Unrepeatable events, uniqueness, meaning, experience, place \\
\hline Economic approaches & $\begin{array}{l}\text { Exploration on the agrarian sector of capitalism (Weber), } \\
\text { examining manufacturing, consumer relations }\end{array}$ \\
\hline Modernizing approaches & $\begin{array}{l}\text { Efforts to modernize agriculture, land reforms to maximize } \\
\text { profits }\end{array}$ \\
\hline Environmental approaches & $\begin{array}{l}\text { Return to nature, imaginative tradition of agriculture, } \\
\text { environmental protective critical approach, emancipation of } \\
\text { nature, critique of consumer society, greenwashing, } \\
\text { environmental ethics, anthropocentrism, biocentrism, } \\
\text { ecocentrism }\end{array}$ \\
\hline Social emancipation & Reduced inequality, social justice, poverty, social stratification \\
\hline Bottom - up & $\begin{array}{l}\text { Community Planning, NGO sector, proximity to local area } \\
\text { problems, renewal of local sources }\end{array}$ \\
\hline Top - down & $\begin{array}{l}\text { State planning, regulation, legislation, protection of social } \\
\text { justice, grants }\end{array}$ \\
\hline Technocratic approach & $\begin{array}{l}\text { Maximizing profits from land agro-technologies, } \\
\text { quantification, automation, artificial intelligence }\end{array}$ \\
\hline Behaviorism & $\begin{array}{l}\text { Studying the behavior, such as the preference for acting } \\
\text { (incomplete information), personal preferences, habits, not to } \\
\text { maximize profit by all means but focus on individual } \\
\text { reasonable profit }\end{array}$ \\
\hline Neo-Marxism & $\begin{array}{l}\text { Analysis of inequality, critique of capitalism, the impact of } \\
\text { social class on an individual's life }\end{array}$ \\
\hline Regional development & Development of marginalized regions \\
\hline Sustainable & $\begin{array}{l}\text { Balanced "social, economic and environmental approach" } \\
\text { against liberalism and preference of economic development }\end{array}$ \\
\hline
\end{tabular}

Source: author, according Hynek, Vávra, 2011; Antrop, 1998; Delín, Posp ch, 2016

LPIS provide geospatial information about agricultural land use. Analyses of LPIS show the conflict between agricultural and non-agricultural land use in the context of the metropolitan area and also the conflict of the spontaneous process and planned action of man (Antrop, 1998, Forman , Godron, 1986). Land parcel identification system provides the alternative source of land use data to the national statistic (cadastral data). LPIS also often provides better accuracy than widely used satellite data (CORINE Land Cover Changes data). LPIS is 
used very rarely in studies of metropolitan areas because LPIS is a relatively innovative source, data were difficult to obtain and are focused only on nonagriculture land use and on farmers receiving subsidies. One of the most important goals of paper is therefore to verify, whether LPIS data will indicate similar results as widely used data of Cadastral statistic (used by Budňáková et al. 2015, Bičik et al., 2009).

\section{Land use changes}

The most significant changes in land use changes over a period of 150 years in the CR are associated with the results of the second world war and following expulsion of the German population, the nationalization of land (repressive collectivization), the land reform in the 20s of the 20th century, the economic, political and social revolution in 1989, the entrance to EU and recently with the common agricultural policy (Bičík, Jeleček, 2009). In the process of change under study Druga and Falt’an (2014), social driving forces (collectivization) were stronger than natural determination (soil, slope). In reality, these effects stand together in a wide spectrum of driving forces.

The accession of the Czech Republic to the EU in 2004 supports trends in post-productivism in the agricultural sector (Svobodová, 2014, Věžník et al., 2013). Geographically it led to a more intensive use of fertile land in lowlands and to a gradual conversion of less fertile soils of highlands and mountains into permanent grasslands or forests. (Bičík et al., 2001, Demek et al., 2012).

A key structural phenomenon in the use of agricultural land lies in the increase of areas of grasslands after 1990 (Bičík et al., 2010); expanding of grasslands in the last period is further accelerated by EU Common Agricultural Policy (Némethová, 2014). Intensive farming mechanization, large land blocks, fertilization with consequent disruption to food chains, deterioration of soil, negative impact on water and other problems were solved through postproduction policies (decoupling, health check, cross-compliance, and Rural Development Programme) (Stoate et al., 2009), which led to increasing area of grasslands in the Czech Republic.

The grassing of land is a key tool for reducing water erosion. Fifty percent of agricultural land in the CR is threatened by water erosion (Budńáková et al., 2012). Taking the steepest parcels out of production is the most effective way to lower the mean annual sediment export (Van Rompaey, 2007). The grassing is considered positive, because the fact that changes from grassland to arable land, in particular, can lead to significant carbon dioxide (CO2) emissions due to both aeration and disruption of stabilising soil aggregates below-ground, and the loss of vegetation above-ground (Roberts, Chan, 1990, Zimmermann et al., 2016). On the other side, according to the EU rural scenarios up to 2030, one of the most striking features of the European landscape consists of land taken out of agricultural production (Metzger et al., 2006; Stoate et al., 2009, (Plieninger et al. (2016)). Abandoned land also creates the problem of invasive plant species with self-seeding trees, which produce so-called "new wilderness" (Lipský, 2000). Except soil sealing and land abandonment, energetic themes in land use change are important (solar plants and the decrease of organic matter, because 


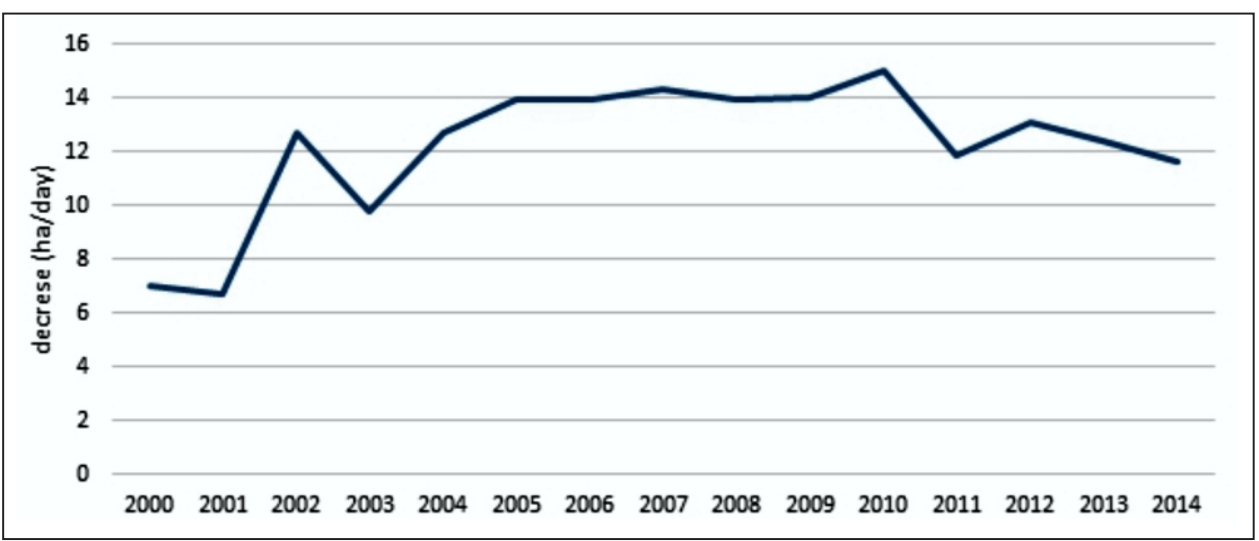

Figure 1. Daily decrease of agricultural land in the Czech Republic based on cadastre data

Source: Budňáková et al., 2015 according to data of Cadastre

of biogas station).

Important change refers to the reduction of landscape heterogeneity and change towards a simpler land use pattern in the Czech Republic over last 150 years (1845-2000) (Lorencová et al., 2013, Sklenička, Pixová, 2004,). For example, across the European continent, $42 \%$ of mammals and $15 \%$ of birds are threatened by the loss of biodiversity. (Urban Soil Management Strategy, 2012).

Arable land in the Czech Republic was converted into permanent grassland (for the period 1948-2010), especially in the northern and partially on the eastern borders of the country. (Lorencová et al., 2013). Grassing is supported by agro-environmental measures in specific areas and soil conditions (LFA areas, areas with higher slope $\left(>10^{\circ}\right)$, on shallow, sandy, waterlogged or very heavy soils, in the highly erosion-endangered areas, in areas particularly protected, in areas vulnerable to nitrates and areas near watercourses or water resource protection zones (Budňáková et al., 2015). The research was motivated with the greatest amount of soil sealing in metropolitan areas. The radical transformation of suburban hinterland after 1990 in many socialistic countries affected to the urban sprawl. (Gr dinaru et al, 2015).

According to the European Environment Agency, since the mid-1950s the total surface area of cities in the EU has increased by $78 \%$, whereas the population has grown by only $33 \%$. Land take was about $1000 \mathrm{~km} 2$ annually in EU (in the period 1990 - 2000), (European Commission, 2016). But there are differences between cities due to the many factors, for example, density Kasanko et al (2006). Driving forces of decrease of agricultural land were studied with many authors. Bürgi et al. (2004) describe 5 types of driving forces: socio-economic, political, technologic, natural and cultural. Geist a Lambin (2007) used minimally different driving forces, Van Vliet et al. (2016) used also institutional driving forces, which recognize as most important. In the Czech Republic, there are losses of agricultural land on average between 1999 - 2014: 13 ha/day (Figure 1).

A number of experts criticized phenomenon of soil sealing (Bičík et al., 2010). Changes from agricultural to non-agricultural uses are except the changes to build up areas also caused by afforestation. The conversion of 
farmland to non-agricultural use is, according to many authors, supported especially by proximity to a settlement, i.e. the distance to the edge or the center of the nearest municipality (e.g. Cheshire, 1995; Guiling et al., 2009; Naydenov, 2009 all in Sklenička, Pixová, 2004). The annual impact of soil losses, due to urbanization on the production capability of agriculture in the EU 25 has been estimated to be equivalent to the loss of more than 4.4 million of tonnes of wheat (Gardi et al., 2009 in Huber, Kurzweil, 2012). Sýkora and Ouředníček (2007) in the case of Brno and Prague described the main process in metropolitan areas as (1.) non-residential deconcentration (retail and warehousing: hypermarkets) with more important effect than (2.) residential deconcentration (individual housing). Soil sealing also is driven by employment deconcentration (green field industrialization, administrative centers), where localization is based on transport possibilities (near highways, airports, and nodes).

This kind of process is joined with the decrease of arable land and possible risk of creation of new "brownfield" of buildings of warehouse and parking places. Similar processes with the loss of agricultural land in the territory of Bucharest metropolitan area are described in Simion (2010). The negative impact of soil sealing is created with non-conceptionaly building or construction against the urban plan. Special example of decrease of agricultural land in Brno metropolitan area was construction of solar plants, which was based on misused environmental ideology, Solving of problems can be found for example in Urban Soil Management Strategy for the secure sustainable use of soil resource. There are two goals: 1. Reduction of the quantity of soil consumption rate and soil sealing, 2. Sustainable use of soil considering soil quality (provision of soil functions). Goals are solved by following tools: 1. Soil quality evaluation tools, 2. Supporting tools for the implementation of strategies, 3. Tools of awareness raising. (Urban Soil Management Strategy, 2012). Exchange of information between science disciplines, practitioners and policy makers across Europe will be essential to the future policy (Stoate et al., 2009).

The investigation and applications in Urban Soil Management Strategy at the pilot sites have clearly revealed that different characteristics and planning levels of sites require appropriate strategies and tools. The experiences showed that the urban planning departments, as key actors in land take, highly welcome aspects of soil protection in planning procedures, but they themselves cannot implement the Urban Soil management system strategies and tools due to lack of time and competence. Therefore, they need a provision of facts, data, arguments, and figures ready for the planning and approval procedures prepared by soil experts (Urban Soil Management Strategy, 2012).

\section{Material and method}

The study is focused on Brno metropolitan area (BMA). Brno is the second largest city in the Czech Republic. Delimitation of BMA was used according to delimitation for integral territorial investments strategies (ITI) (Mulíček et al, 2015a). In 2012 there were 167 municipalities with population of 609114 inhabitants (6\% of population of Czech Republic). Administrative delimitation of center of BMA (Brno-city) has usually resident population of 384277 inhabit- 


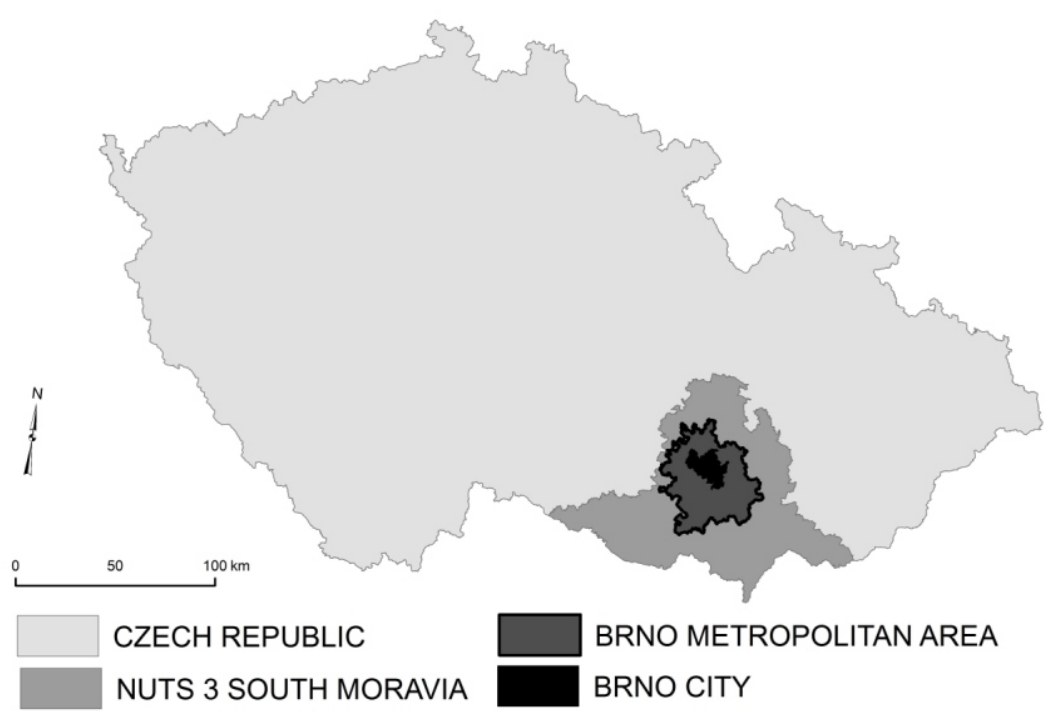

Figure 2. Position of Brno metropolitan area in the Czech Republic Source: author

ants.

For the purposes of this article, the agricultural changes are defined as geographical (territorial) land-use changes of agricultural land:

1. according to LPIS as temporal change between categories utilised agricultural land.

2. according to the Cadastre as temporal changes between categories of agricultural land.

The correct interpretation of land use changes is based on correct understanding of the data source. For the purposes of this study, the two most important sources in two time cuts were compared: 31. 12. 2008 and 31. 12. 2013. There were two sources of data:

1. LPIS (Land parcel identification system). LPIS contains data of utilised agricultural area which is registered for subsidies for farmers. The Czech LPIS was established in 2004 and it contains geospatial data of field blocks. The disadvantage of the system is the fact that data do not contain the land of farmers, who do not apply subsidies (small private owners, estimates states that it is the very small minority). The areas below the minimum size of field blocks (0.01 ha) are not included. Utilized agriculture land also does not include fields called as "areas not used for agricultural purposes" (gardens for recreational purposes, cottage gardens, golf courses, solar powers, fallow land - without subsidies, etc.) (Ministry of Agriculture, 2014). Field blocks data of LPIS were obtained from the Ministry of Agriculture (Ministry of Agriculture 2008, 2013).

2. Data of State Administration of Land Surveying and Cadastre (Cadastre). Cadastral data come from spatial analytical data published by Czech Statistical Office for all 6250 municipalities of CR. (Czech Statistical Office, Czech Office for Surveying, Mapping and Cadastre 2008, 2013). These data are the most common source of land use statistics of Czech Republic and they are created by State Administration of Land Surveying and Cadastre (Č́̇ZK), also 
called as Cadastre of Real Estates and published by Czech Statistical Office. Cadastral data contain one value (i.e. size of the area of agricultural land) for one municipality. The disadvantage is the fact that they include agricultural land, which is not cultivated (fallow land, land covered with small trees) (i.e. new wilderness, Lipský, 2000), areas of private gardens, areas of significant landscape elements (solitary trees, poles, stones), areas with solar plants registered as agriculture land, waterlogged not cultivated areas, not up-to-date areas.

According to LPIS, there are about 3.54 mil ha of utilized agriculture area in the Czech Republic, Cadastre registers 4.22 mil. ha of agriculture land in 2013. The difference about 680.4 thousand ha is caused by gardens (163 thousand ha) and by other non-utilized areas (fellow land, new forests). The cadastre data are updated more slowly; it is assumed that a large part of the area of registered 'arable land' is in reality permanent grassland.

LPIS data were processed in ArcGIS 10.2. The source of LPIS contained also data, which described non-agricultural land which has been registered as utilised land. In LPIS there are more types of land use: cropland, permanent grassland, orchards, vineyards, not-permanent grassland etc., there are also two groups which were erased from base dataset: ponds and afforested agricultural land (insignificant area of 20 ha in 2008 and 39 ha in 2015, $0.02-0.04 \%$ of agricultural land of BMA area). Two layers 2008 and 2013 were exported to ArcGIS and POSTGRES SQL PostGIS). Changes have been detected using the Tools Overlay - Symmetrical Difference that calculates increases and decreases of areas. Gains and losses of areas were further summarized by municipalities (union) and selected by attribute properties. Other used commands consisted of summarizing, intersecting, identifying and joining. With the help of tool Symmetrical differences, areas of increases and decreases of areas were created.

There were used quantitative methods used in processing (Bičík et al., 2010). For each municipality in the BMA in 2008 and 2013 were processed following data:

1. Area of agricultural land according to LPIS, areas of agricultural land according to Cadastre.

2. Difference between the areas in 2008 and 2013.

3. Relativized decreases and increases of areas according to Cadastre

(Formula 1).

4. Relativized decreases and increases of areas according to LPIS

(Formula 2).

5. Correlation between losses and increases between data LPIS and Cadastre. Correlation of relative size of areas ( $\mathrm{X}$ and $\mathrm{Y}$ ) for Cadastre and LPIS was performed. Variables do not have the normal distribution, and therefore

\section{Formula 1}

$$
X=\text { Relative incerease CUZK }=\frac{\text { Agriculture land CUZK 2013 }- \text { Agraculture land CUZK } 2008}{\text { Agriculture land CUZK } 2008}
$$

\section{Formula 2}

$$
Y=\text { Relative incerease LPIS }=\frac{\text { Agriculture land LPIS } 2013-\text { Agraculture land LPIS } 2008}{\text { Agriculture land LPIS } 2008}
$$


Table 2. Agricultural land in Brno metropolitan area according to LPIS and Cadastre

\begin{tabular}{lcccc}
\hline BMA agricultural land & 2008 & 2013 & \multicolumn{2}{c}{ Summary } \\
\hline LPIS decrease & ha & ha & ha & $\%$ \\
\hline LPIS increase & - & - & -1182 & $-1,50$ \\
\hline LPIS total & - & - & 1770 & 2,24 \\
\hline CÚZK & 78858 & 79360 & 502 & 0,64 \\
\hline
\end{tabular}

Spearman's rank correlation index was chosen.

6. Next methods consisted of the comparison of the largest blocks of losses and their localization according to LPIS and Cadastre. The further analysis described the selection of villages with the highest values for LPIS and Cadastre according to the results of the previous analysis. Maps and tables were compared. Interpretation and policy implications were created after study of literature, discussions with around 10 farmers and field research.

\section{Results}

The difference between utilized agricultural area and the total agricultural land by Cadastre are significant. In LPIS, there is registered $81.7 \%$ of total agricultural land according to the Cadastre of BMO in 2013. The proportion of land in the LPIS to Cadastre in the area of the Czech Republic is $83.9 \%$. The advantage of LPIS lies in the possibility of displaying data of spatial differences, which can be used for analyses of significant internal structural changes in the development of land use. Altogether utilized agricultural area according to LPIS increases. Spatial data, however, allow detecting increases and decreases separately. Decreases of LPIS taken separately (-1182 ha) outweigh the overall losses by data of Cadastre (-693 ha).

The differences are determined by the nature of source data described in the methodology. Maps of agricultural land use changes according to LPIS and Cadastre show that maximum decreases according to LPIS and Cadastre are located in different municipalities.

According to the Cadastre, areas of agricultural land decline in general. There are also several villages, where area increases, but the overall land decreases. Areas registered in LPIS altogether rise. These increases in LPIS are mostly administrative additions, which have previously been also agricultural land but were not recorded in the LPIS because these farmers did not apply for subsidies in the past.

The first hypothesis that data of Cadastre and LPIS are different in BMA was supported. This fact is not unknown, but the problem remains that during the land protecting activities (creation of the new law of protection of agricultural land) the real decline of land resources was found, but data used in this documents (Cadastre data) can be inaccurate, partially outdated, and do not reflect internal changes.

However, LPIS does not contain all agricultural land, its advantage lies in the conclusion, that (unlike Cadastre data) it can be analyzed with geospatial 


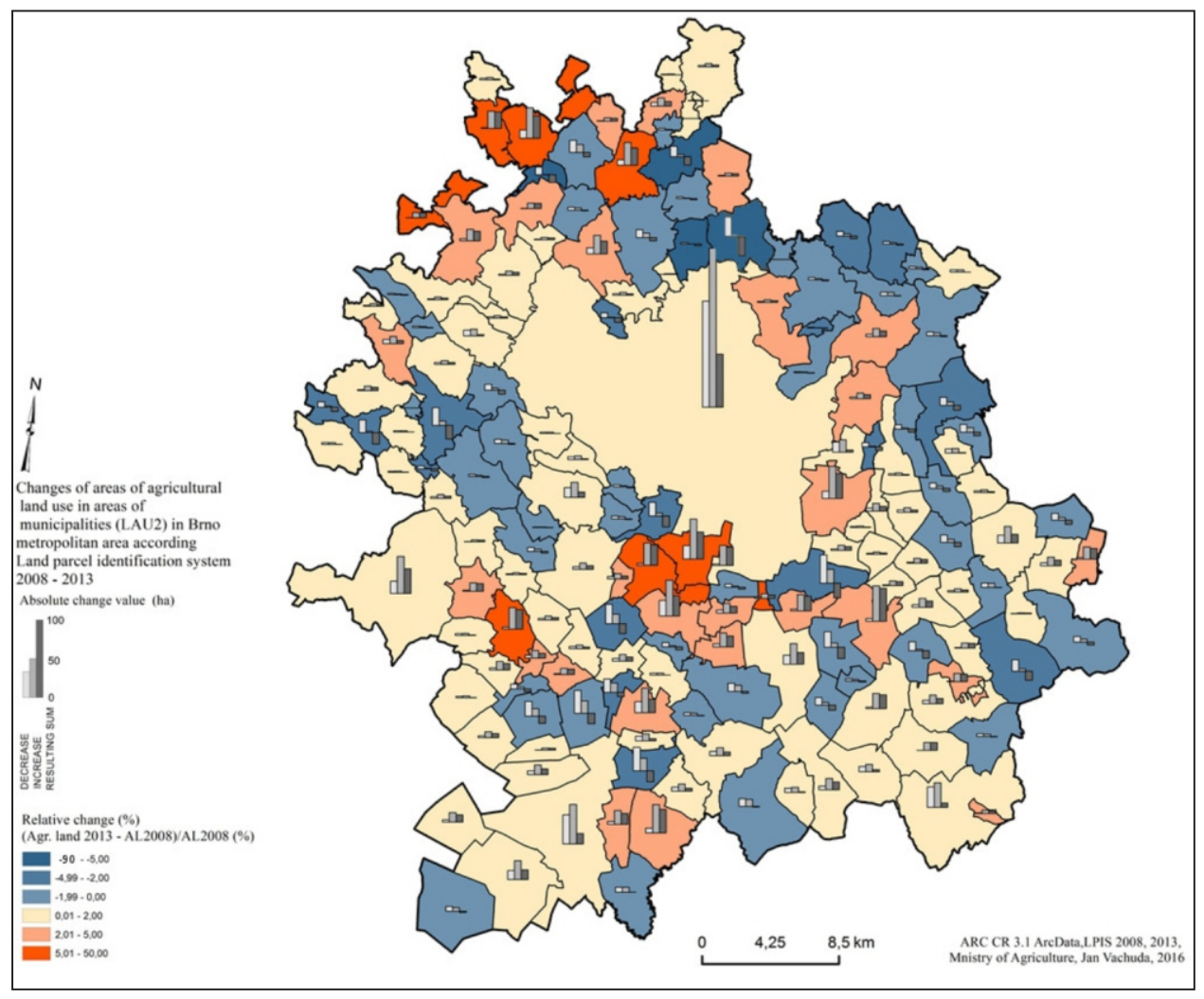

Figure 3. Changes of utilized agricultural areas in Brno metropolitan area 2008-2013 Source: LPIS

location and with decreases and increases in detail. Agriculture land according to Cadastre also approximately contains data, which are not in LPIS due to the update (self-seeding forest, waterlogged areas). LPIS error occurs due to the fact that it only includes land for agricultural subsidies, but it is supposed, that there is a vast majority of utilized agriculture area.

Municipalities with the highest decrease of agricultural land in BMO according to Cadastre show the map (Figure 3). The biggest change in the center of agglomeration is clearly predictable and it is caused by urbanization. Second highest rank is in Slavkov with the decrease of 80.5 ha. Research proved that this change can be caused approximately by the creation of golf playground, which was made in 2000 - 2002. This is partial proof showing that data of Cadastre are outdated. According to Cadastre the decrease in Nemčany (or Vlasatice) is also very high, but the analysis via orthophoto map did not recognize such big change in reality. The change is probably caused by outdated maps of Cadastral office. In this municipalities, land reforms have been carried out and cadastral maps were renewed.

Municipalities with the highest largest absolute decreases according to LPIS data are following: Brno, Pohořelice, Sokolnice, Žabčice, Medlov a Vranov u Brna. The largest decreases in these communities are determined by a housing, solar power plants and increasing the quarries for sand. More detailed analysis of this situation can be found in tab. 5that evaluates the biggest blocks with the loss of agricultural land by LPIS. 


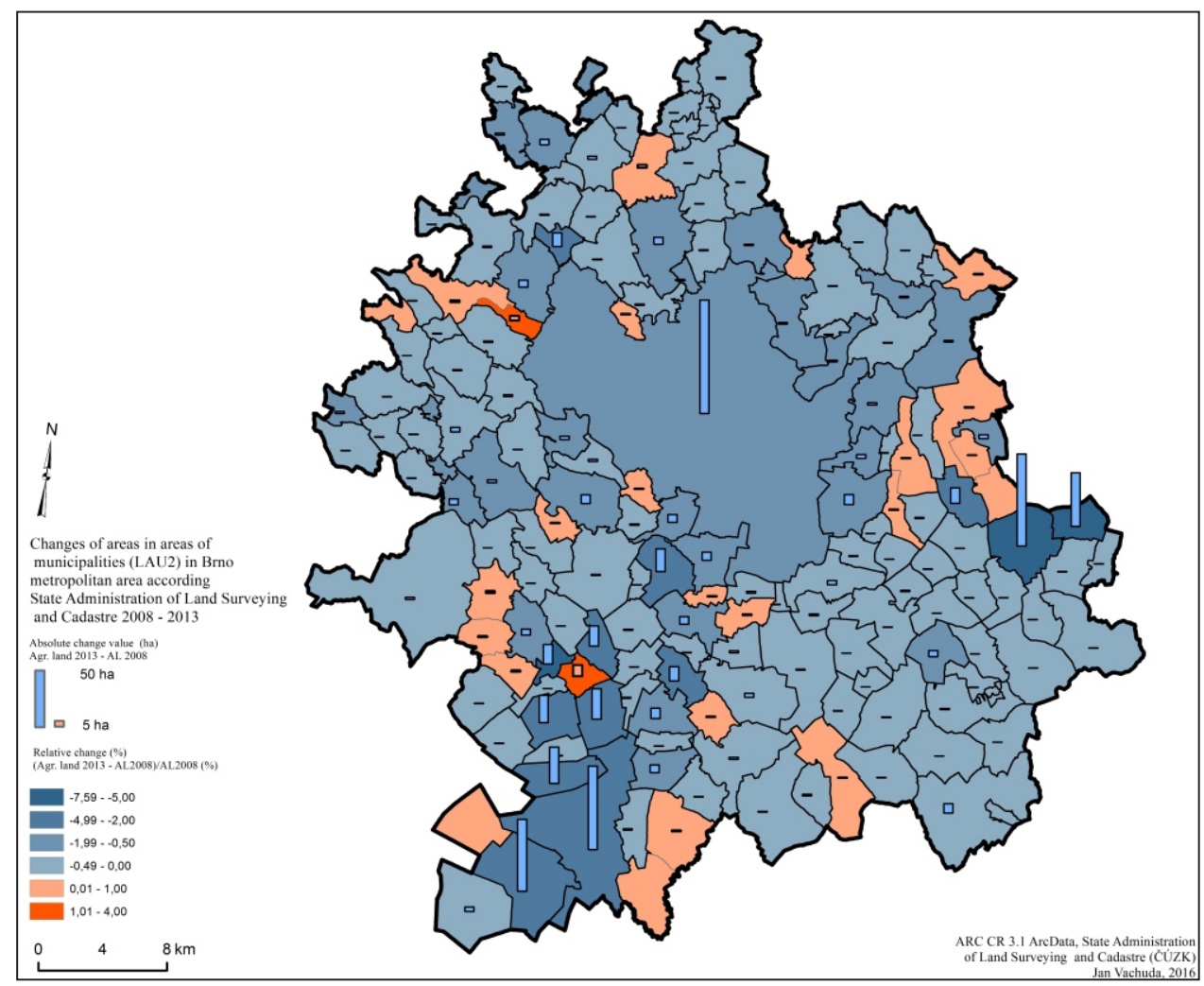

Figure 4. Changes of agricultural areas in Brno metropolitan area 2008-2013 according to Cadastre Source: Cadastre

Maps of changes according to LPIS and Cadastre differ significantly. Large increases by LPIS can be found in region Tišnov, significant total increases are also in two villages in the south of Brno (Želešice, Modřice). Modřice, however, belongs to the territorial unit with the greatest absolute change in LPIS. There is a high decrease, much higher increase and total increase. Contra changes are neglected in cadastral data (decreases and increase are summed in source data) causing big problems with the interpretation (Figure 4). Overall, even in comparison of maps can be concluded that there is a significant difference between data LPIS and Cadastre; the first hypothesis was therefore supported.

Increases of utilized agricultural area are determined by the adding originally not included fields (or. new farmers). Other important areas of increase include orchards in Rajhrad (Háje) Žalešice, Modřice, further specific locality Rajhrad pheasant (Popovice, forests of Mendel University). The increase is also caused by the increase in areas of developers, who had not been originally registered in LPIS but are currently suggested to rent a field and register it in LPIS (location at Olympia, as well as areas between Šlapanice and Brno).

The largest block of increase in BMO is localized between the airport and the highway Tuřany. This block which was previously offered as an attractive industrial zone for developers is currently used for agricultural purposes, but in the future, it is expected non-agriculture utilization and exclusion of LPIS. An 
important part of increases in LPIS consists of recultivation after sand queries (Hrušovany, Žabčice). Increasing and decreasing areas in LPIS are also caused by spatial corrections of LPIS. Agriculture areas had been in some cases mapped personally by farmers, and therefore SZIF (Agency for distribution of agriculture grants) made a correction of spatial demarcation. Increases are not caused by creating of new farmland. Decreases of LPIS agricultural land in the fifteen largest blocks were analyzed in more detail: There are 8 solar power plants in the fifteen largest decreases blocks. Solar plants are mostly situated in the southern part of the metropolitan area, in most favorable agricultural conditions and on a small slope. Only eight cases (of the fifteen largest) caused the total annexation of 137 ha of agricultural land. Seven in cropland, one in orchards. The two biggest changes of LPIS in Brno region (both more than 37 ha) consist of solar power plant Tuřany and Sokolnice. Tuřany solar plant (21.2 ha) is the 4th biggest plant in CR (Czech Energetic Regulation Office, 2015). Next reasons for the decrease are sand quarries, construction of the Czech technological park and residential houses, abandoned orchards and vineyards (Tab. 3)

Differences between data of LPIS and Cadastre were statistically evaluated using a correlation between relative decreases/increases of total areas in LPIS and Cadastre (X and Y, see methodology). Spearman's rank correlation index was used because variables do not have normal distribution: $\mathrm{RSP}=0.076$ ( $\mathrm{p}$ : $0.05)$ is not significant, correlation dependence was therefore not proved. Further analysis (correlation absolute values of agricultural land) also showed that LPIS data are different than data of Cadastre. Due to the administrative nature of the areas of increases of the LPIS, there was conducted correlation between decreases in LPIS agriculture and the overall state of Cadastre, (RSP = 0.38 is relatively significant, but not conclusive). In interpretation is therefore necessary to consider the fact that data on decreases in agricultural land by LPIS and by Cadastre do not correlate.

Both sources of used data are inaccurate. LPIS includes additions. Cadastre includes a wide variety of abandoned land (gardens, raids) and probably contains old data. It is necessary to find the good aspects of both. LPIS is able to provide data on reciprocal changes and shows the high increase of solar power plants. Cadastre data are good for fast orientation in small scale.

Structural changes as the boom of solar plants can be effectively detected by LPIS data. Solar power plants in the open countryside (in many cases) violated the Building Act $\S 18$ par. 5 of Law no. 183/2006 Coll., On territorial planning and building regulations, which did not permit the placement of photovoltaic power plants outside the areas delimited for this purpose out of build-up areas of the municipality. Power plants in the landscape which were allowed for special exceptions or after changes of city plan violate at least the spirit of the law. Solar plants should be placed mainly on the roofs. At present, however, new constructions of power plants have small intensity because state aid had been decreased. State aid was partly transformed to other energetic themes. Highest problems are currently caused by biogas stations if they are cause degradation of soil. Biogas stations should be the only complement of agricultural production not energetic business with grants and maize. Farmers have to respect the good agricultural and environmental condition and produce maize only on part of area, rotate crops because of maize cause high erosion and degradation of land. 
Table 3. TOP 15 largest blocks of decrease of agricultural land in Brno metropolitan area according to LPIS

TOP 15 largest blocks of decrease of agricultural land in Brno metropolitan area

\begin{tabular}{|c|c|c|c|}
\hline Area (ha) & Municipality & Reason of decrease & Notice (company, installed output) \\
\hline 37.91 & Brno, Tu any & Solar power plant Tu any & $\begin{array}{l}\text { BS Park I. s. r. o, south from airport, } \\
(21,2 \mathrm{MW} \text { installed output = } \\
\text { 4. biggest in CR) }\end{array}$ \\
\hline 37.61 & Sokolnice & Solar power plant Sokolnice & FVE Papeno 2 (7.2 MW) \\
\hline 13.23 & Brno & $\begin{array}{l}\text { Czech Technological Park } \\
\text { Brno }\end{array}$ & $\begin{array}{l}\text { INMEC (South Moravia Innovation } \\
\text { Centre) and more, under Palacký } \\
\text { vrch }\end{array}$ \\
\hline 13.08 & Lip vka & Cropland & $\begin{array}{l}\text { partly waterlogged, partly unknown } \\
\text { reason }\end{array}$ \\
\hline 12.26 & Medlov & Solar power plant & Gilose s. r. o. (3.6 MW) \\
\hline 11.67 & Žabcice & Sand quarry & Pískova Žabcice, Zadní ctvrtky \\
\hline 11.65 & Zak any & Solar power plant & FVE Papeno \\
\hline 10.68 & Malešovice & Solar power plant & NOBILITY ENERGY a.s. \\
\hline 10.54 & Žabcice & Solar power plant & $\begin{array}{l}\text { CEZ Obnovitelné zdroje, s.r.o. } \\
(5,6 \mathrm{MW})\end{array}$ \\
\hline 10.15 & $\begin{array}{l}\text { Klobouky u } \\
\text { Brna }\end{array}$ & Vineyards & \\
\hline 8.58 & Syrovice & Solar power plant & Sun Power s. r. o. \\
\hline 8.50 & $\begin{array}{l}\text { Kobe ice u } \\
\text { Brna }\end{array}$ & Orchards & locality "Damborský kopec" \\
\hline 7.88 & Rosice & Solar power plant & FV Rosice, s. r. o. \\
\hline 7.80 & Poho elice & Housingestateproject & locality "Za cukrovarem" \\
\hline 7.72 & Hrušovany & Sandquarry & \\
\hline
\end{tabular}

Source: LPIS, Czech energetic regulation office

\section{Discussion}

The first hypothesis, that agriculture land data of LPIS and Cadastre are different in Brno metropolitan area, was supported. Documents, which are used by experts to change legislation, may simplify the situation, if they use for analyses about the decrease of agricultural land only one source - Cadastre. LPIS is also the important resource that helps to understand changes of agricultural land use.

The second hypothesis: "using the LPIS data for assessing land use changes will increase the accuracy of land use changes understanding in Brno Metropolitan Area, because LPIS is spatial more precise then cadastral statistic", was partly supported, but not totally because also data of LPIS are not totally precise. However, geospatial information of LPIS helps more in spatial analyses. Blocks of solar powers and sand quarries can provide better information than one value for one village according to cadastral statistic data. For this scale, the 
data of LPIS are also better than Corine Land Cover Changes 2006-2012 data because of their resolution of images, where small changes cannot be recognizable.

The third hypothesis, that localization of the highest decrease is located near areas with high residential and industrial suburbanization was supported partly. It was revealed that solar power plants and quarries cause highest decreases according to LPIS. Residential and industrial urbanization (out of administrative Brno-city) was not so important. Nowadays, due to the decline of constructions of solar plants, it may predominate again. Energetic business change very fast, therefore, it is supposed that solar plants will be beneficial also without of subsidies or new technologies (i.e. microbial fuel cells) can spread.

The article deals with the most accessible and objective spatial data and is affected by the problem of so-called "Spatial science." Due to the surprising finding of very high decreases of agriculture land due to photovoltaic power plants, it is necessary to move to a deeper explanation of these processes.

Solar power plants are a typical example of the misuse of environmental ideology to redistribution of state money to the relatively narrow group that had information and capital, which partly decided on the setting of conditions of solar subsidies or was able to utilize the aid in a short term. The key process in the background was the inability (unwillingness) of government to quickly intervene and change the conditions including the speed of innovation of solar technology, which caused the decline of prices of panels. Partially it was a failure of spatial planning and the Energy Regulatory Office, respectively yielding of strong lobbying and pressure.

Stronger automatic regulations to reduce the profitability of the subsidies according to current market situation could solve this problem at that time.

Critical analysis of the use of LPIS data has to point out disadvantages of nomothetic research. The best geospatial data from LPIS cannot provide information about internal relations and decisions taken by farmers. Data in LPIS increase spatial accuracy and in attribute table provide more data for further interpretation, which may shift land use research to more accurate analyses, but they cannot eliminate fundamental philosophical limitations inherent to nomothetic research, where are compared incomparable things (unique places, unique actors).

Huber, Kurtweil (2012) described the concept of implementing soil management strategies. After analysis of actual situation and problems of soil consumption, they suggest 1 . selection and application of suitable soil management tools and 2. introduction of activities on awareness raising. The author attempts to outline some possible recommendations for government in Brno agglomeration (find out in literature, discussions and field research with farmers) which are mainly focus on awareness raising):

1. More emphasis on building and soil sealing only in the urban build-up areas.

2. More emphasis on the proper functioning of the building authorities and their control, on an education of officers, transparency. Planning authorities are key players and do not have time to procure sufficient data, which would thus be transmitted as easily as possible with current technology.

3. Optimization of a development of individual housing and uncontrolled 
suburbanization using planning tools and teaching people. Regulate and inform about the negative aspects of suburbanization and their cycles.

4. Allocate greater financial resources on land reforms that update data of maps, solve erosion and land abandonment.

5. Promote responsibility for landowners, even though they lease fields to agricultural companies, support small farmers with responsibility for their own land, promote gardening, discourage large capital companies speculating on land (reduction of sales of municipal land to speculators). Landowners should control good condition of an agricultural practice on leased land.

6. Promote the concept of sustainable management, greater emphasis on the rational use of new energetic technologies, especially biogas stations (not only for great agriculture companies with a dominance of maize but also for cogeneration of heat and (re) utilization of waste with biomass), increased charges for land taking away of agricultural purpose.

7. Emphasis on the penetration of innovation, examples of good practice, the harmonization of approaches bottom-up and top-down, emphasize on young farmers, promotion of agro-tourism. Agricultural land-saving innovation, for example, benefits from increasing regional demand for organic food.

8. Support environmental education and report on indicators of quality of life, which are dependent on the value of the environment which stand apart from the (abused) economic indicators (GDP, the amount of agricultural production etc.).

9. Simplify procedure to obtain subsidies (reduce the administrative burden / cheaper / simplify, especially for small farmers)

10. Focus on Global Challenges: Global warming, rapid rainfall, droughts and floods, renewable energy resources.

11. Support further research into the use of shared information systems (such as VGI (volunteered geographic information: Open Street Map, and other technologies), followed by interpretation of shared information and their implementation to improve the situation (participatory governance, cooperation, open data, transparency and other social innovations).

12. Emphasis to the theoretical basis of environmental ethics.

\section{Conclusion}

The article evaluates changes in agricultural land in Brno metropolitan area. Paper introduced the complexity of theme and approaches to solve the issue. It was found that there are significant differences between the changes of utilized land and changes in the overall agricultural land. Suggestions for improving the system: data from LPIS and from Cadastre should have an interface for creating automated reports on the territory. Automation computing facilitates interpretation. The research results should be reflected in legislation and methodologies. Partially this goal was successful. The Law on the Protection of agriculture land fond or implementation of the Greening of the CAP include in themselves the results of research on the decreases of land. The next step is to check compliance by farmers and owners. Finally, education and relationship to the land are considered of high importance. A number of solutions to address the situation 
was also proposed, which can be used for raising awareness about land use changes.

\section{Acknowledgements}

The author would like to thank to the Ministry of Agriculture, editors of the journal and to the grant: „MUNI/A/1315/2015 Integrovaný výzkum environmentálních změn v krajinné sféře Země.” (Integrated research of environmental changes of landscape).

\section{References}

Antrop, M., (1998). "Landscape change: Plan or chaos?", Landscape and Urban Planning, vol. 41. nr.3.p.155-161.

Balej, M., Anděl, J., (2011). "Typology of the districts in Czechia based on land cover structure”, Geografie, vol. 116, nr. 2 .p. 172-190.

Bičík, I. et al.,(2010). "Změny využití ploch v Česku 1845-2000”, Praha: Nakladatelství ČGS, 250 p.

Bičík, I., Jeleček, L., (2009). "Land use and landscape changes in Czechia during the period of transition 1990-2007”, Geografie Sbornik ČGS, vol. 114. nr. 4. p. 263-281.

Bičík, I., Jeleček, L., Štěpánek, V., (2001). "Land-use changes and their social driving forces in Czechia in the 19th and 20th centuries",Land Use Policy, vol. 18. nr.1.p. $65-73$.

Budňáková, M., et al., (2012). "Situační a výhledová zpráva půda”, Mze, Praha, 4 may 2016, (http://eagri.cz/public/web/file/181775/Zprava_Puda_kniha_web_1_.pdf).

Budňáková, M., et al., (2015). "Situační a výhledová zpráva půda“, [online] Mze, Praha, 4 may 2016, (http://eagri.cz/public/web/file/442693/SVZ_Puda_2015.pdf).

Bürgi, M., Hersperger, A. M., Schneeberger, N., (2004). "Driving forces of landscape change-current and new directions", Landscape Ecology, vol. 19, pp. 857-868.

Czech Statistical Office, Czech Office for Surveying, Mapping and Cadastre (2008, 2013).:Data about municipalities - Územně analytické podklady, Praha: Czech $\begin{array}{llll}\text { Statistical may } & \text { Office, } & 25 & \end{array}$ (http://www.czso.cz/csu/redakce.nsf/i/csu_a_uzemne_analyticke_podklady).

Czech energetic regulation office, (2015). "License of solar plant Brno - Tuřany (BS Park I. s.r.o.)", Czech energetic regulation office, 4. may 2016, (http://licence.eru.cz/detail.php?lic-id $=110910415 \&$ sequence $=1 \&$ total $=1$ )

Demek, J., Mackovčin, P, Slavík, P., (2012). "Spatial and temporal trends in land-use changes of Central European Landscape in the last 170 years: a case study from the south-eastern part of the Czech Republic", Moravian Geographical Reports, vol. 20. nr.3. p.2-21. ISSN 1210-8812.

Delín, M, Pospěch, P., (2016). "Vývoj př́istupů ke zkoumání venkova v rurální sociologii”, Sociológia, vol. 48. nr.1. p. 5-24.

Druga, M., Faltan, V., (2014). "Influences of environmental drivers on land cover structure and its long-term changes: A case study of the villages of Malachov and Podkonice in Slovakia”, Moravian Geographical Reports, vol. 22.nr.3.p. 29-41. DOI: $10.2478 / \mathrm{mgr}-2014-0016$

European Commission, (2016). "Soil Sealing. European Commission Environment Directorate-General", 5.2.2016,(http://ec.europa.eu/environment/soil/sealing_guidelines.htm).

Feranec, J., Š́ri, M., Ot’ahel', J., Cebecauer, T., Kolář, J., Soukup, T., Zdeňková, D., Waszmuth, J., Vâjdea, V., Vîjdea, A.M., Nitica, C., (2000). "Inventory of major landscape changes in the Czech Republic, Hungary, Romania and Slovak Republic 
1970s-1990s", International Journal of Applied Earth Observation and Geoinformation. vol. 2, nr. 2 p.129-139.

Forman, R., Godron, M., (1986). Landscape Ecology. Wiley, New York.

Geist, H. J., Lambin, E. F., (2002). „Proximate Causes and Underlying Driving Forces of Tropical Deforestation“, BioScience, vol. 52. nr. 2. p. 143-150. doi: 10.1641/00063568(2002)052[0143

Grădinaru, S. R., Iojă, C. I.,Onose, D. A., Gavrilidis, A. A., Pătru-Stupariu, I., Kienast, F., Hersperger, A. M., (2015). „Land abandonment as a precursor of built-up development at the sprawling periphery of former socialist cities," Ecological Indicators, vol. 57, p. 305-313, ISSN 1470-160X, http://dx.doi.org/10.1016/j.ecolind.2015.05.009.

Huber, S, Kurzweil, A. (2012). "Soil in legislation and planning”, in Huber, S, Kurzweil, A. (eds) Guide Municipal Soil Management. Department for Environmental Protection, $\begin{array}{llllll}\text { Germany, } & \text { Stuttgart. } & 57 & \text { p, } & 5 . & 2 .\end{array}$ (http://www.umweltbundesamt.at/fileadmin/inhalte/urbansms/pdf_files/final_results/08_ Guide_for_municipal_soil_management.pdf)

Holloway, S. L., Rice, S. P., Valentine, G. (2003). “Key concepts in geography”,1st publ. London, Sage Publications, 342 p.

Hynek, A., Vávra, J., (2011). "Dešifrovací klíč k současným geografiím aneb Úvod do

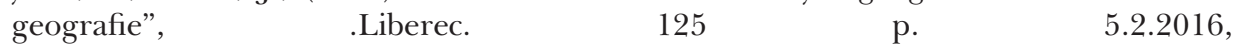
(https://www.kge.tul.cz/attachments/article/327/Desifrak.pdf).

Mulíček, O, Seidenglanz, D., Francke, D., Malý, J., (2015a). "Vymezení funkčního území Brněnské metropolitní oblasti a Jihlavské sídelní aglomerace”, 68 s.. 5.2.2016, ((https://www.brno.cz/iti/vymezeni-uzemi-brnenske-metropolitni-oblasti-bmo/).

Mulíček et al. (2015b). "Atlas Brněnské metropolitní oblasti”, Kancelář strategie města Brna, Brno, 41p. 5.2.2016, (https://www.brno.cz/fileadmin/user_upload/sprava_mesta/Strategie_pro_Brno/dok ume nty/iti/final_Atlas-BMO-komplet-preview.pdf).

Némethová, J., Dubcová, A., Kramáreková, H., (2014). “Impacts of the European Union's common agricultural policy on agriculture in Slovakia”, Moravian Geographical Reports, vol. 22 nr.4 p. 51-64. DOI: 10.1515/mgr-2014-0023.

Kasanko, M., Barredo, J.I., Lavalle, C., Mccormick, N., Demicheli, L., Sagris, V., Brezger, A., (2006). "Are European Cities Becoming Dispersed? A Comparative Analysis of Fifteen European Urban Areas”, Landscape and Urban Planning, vol. 77, p.111-130.

Kuhn, T. S., (1962). „Structure of scientific revolutions“, The University Of Chicago Press, Chicago, $210 \mathrm{p}$.

Levin, G., (2013). "Applying parcel-specific land-use data for improved monitoring of semi-natural grassland in Denmark", Environmental Monitoring and Assessment, vol. 185. nr.3. p. 2615-2625.

Lipský, Z., (2000). “Sledování změn v kulturní krajině”, ČZÚ, Praha, 72 s.

Lorencová, E., Frélichová, J., Nelson, E., Vačkár, E.,(2013). "Past and future impacts of land use and climate change on agricultural ecosystem services in the Czech Republic", Land Use Policy, vol. 33.nr. 2. p. 183-194. ISSN 0264-8377. http://dx.doi.org/10.1016/j.landusepol.2012.12.012.

Ministry of Agriculture, (2008, 2013). "Maps (Data) of LPIS (Land parcel identification system)" (31.12.2008 and 31.12.2013) (offline). Praha: Ministry of Agriculture.

Ministry of Agriculture, (2014). "Metodický pokyn pro aktualizaci evidence půdy", Praha, $\begin{array}{lllll}\text { Ministry of } & \text { Agriculture, } & 22 . & 4 . & 2015 \text {, }\end{array}$ (http://eagri.cz/public/web/mze/farmar/LPIS/metodicke-pokyny/metodicky-pokyn-proaktualizaci-evidence.html ).

Plieninger, T., Draux, H., Fagerholm, N., Bieling, C., Bürgi, M. et al., (2016). "The driving forces of landscape change in Europe: A systematic review of the evidence", Land Use Policy, vol.57 nr.30. p. 204-214, ISSN 0264-8377, http://dx.doi.org/10.1016/j.landusepol.2016.04.040 
Roberts, W.P., Chan, K.Y., (1990). "Tillage-induced increases in carbon-dioxide loss from soils.”, Soil Tillage Resource, vol. 17. nr. 1. p. 143-151.

Van Rompaey, A., Krasa, J., Dostál, T., (2007). "Modelling the impact of land cover changes in the Czech Republic on sediment delivery", Land Use Policy, vol. 24. nr.3. p. 576-583, ISSN 0264-8377, (http://dx.doi.org/10.1016/j.landusepol.2005.10.003)

Rounsevell, M.D.A., Reginster, I., Araújo, M. B., Carter, T.R., Dendoncker, N., Ewert, F., House, J.I., Kankaanpää, S., Leemans, R., Metzger, M.J., Schmit, C., Smith, P., Tuck, G., (2006). "A coherent set of future land use change scenarios for Europe". Agric. Ecosyst. Environment, vol. 114. p. 57-68.

Simion, G., (2010). "The spatial changes of land use in the Bucharest metropolitan area 1970 - 2000s”, Human geographies - Journal of Studies and Research in Human Geography, vol. 4. nr. 2, p. 115-123.

Sklenička, P., Pixová, K., (2004). Importance of spatial heterogeneity to landscape planning and management. Ekologia Bratislava, vol. 23, suppl. 1, p. 310-319.

Skokanová, H., Havlíček, M., Borovec, R., Demek, J., Eremiášová, R., Chrudina, Z., Mackovčin, P., Rysková, R., Slavík, P., Stránská, T., Svoboda, J., (2012).”Development of land use and main land use change processes in the period 1836-2006: case study in the Czech Republic.” Journal of Maps, p. 88-96. DOI: 10.1080/17445647.2012.668768.

Stoate, C., Báldi, A., Beja, P., Boatman, N.D., Herzon, L., Van Doorn, A., De Snoo, G.R., Rakosy, L., Ramwell, C., (2009). "Ecological impacts of early 21 st century agricultural change in Europe - A review” Journal of Environmental Management, vol. 91. nr. 1. p. 22-46. ISSN 0301-4797, (http://dx.doi.org/10.1016/j.jenvman.2009.07.005).

Svobodová, H., 2014. "Changes on Foreign Trade in Agricultural Commodities in the Czech Republic.” Journal Central European Agriculture, International Editorial Board (IEB) JCEA, vol. 15. nr. 2. p. 62-72. ISSN 1332-9049. doi:10.5513/JCEA01/15.2.1453.

Sýkora, L., Ouředníček, M., (2007). "Sprawling post-communist metropolis: commercial and residential suburbanisation in Prague and Brno, the Czech Republic" in: Razin, E., Dijst, M., Vázquez, C. (eds.) Employment Deconcentration in European Metropolitan Areas: Market Forces versus Planning Regulations. Dordrecht, Springer. pp. 209-233. ISBN 978-1-4020-5761-8.

Urban Soil Management Strategy, (2012). "Soil in the City, Department for Environmental Protection, Germany, Stuttgart." 17p. 5. 2. 2016, (http://www.umweltbundesamt.at/fileadmin/inhalte/urbansms/pdf_files/final_results/UR BAN_SMS_Brochure_for_Internet.pdf)

Věžník, A., Král, M., Svobodová, H., (2013). "Agriculture of the Czech Republic in the 21 st Century: From Productivism to Post-productivism." Quaestiones geographicae, Poznań. vol. 32. nr. 4. p.7-14.

Van Vliet, J., De Groot, H.. L. F., Rietveld, P. P., Verburg H., (2015). "Manifestations and underlying drivers of agricultural land use change in Europe." Landscape Urban Planning, nr. 133, pp. 24-36.

Woods, M., (2005). "Rural Geography" London, Sage, 330 p.

Zimmermann J., González, A., Jones, M. B., O'Brien, P., Stout J. C., Green, S., (2016). "Assessing land-use history for reporting on cropland dynamics-A comparison between the Land-Parcel Identification System and traditional inter-annual approaches", Land Use Policy, vol. 52. nr. 2.p.30-40. ISSN 0264-8377, http://dx.doi.org/10.1016/j.landusepol.2015.11.027. 